This item was submitted to Loughborough's Research Repository by the author.

Items in Figshare are protected by copyright, with all rights reserved, unless otherwise indicated.

\title{
Evaluation of alternative intersection treatments at rural crossroads using simulation software
}

PLEASE CITE THE PUBLISHED VERSION

https://doi.org/10.1080/15389588.2018.1528357

PUBLISHER

Taylor \& Francis @ Monash University Accident Research Centre

VERSION

AM (Accepted Manuscript)

PUBLISHER STATEMENT

This is an Accepted Manuscript of an article published by Taylor \& Francis in Traffic Injury Prevention on 17 Dec 2018, available online: https://doi.org/10.1080/15389588.2018.1528357

\section{LICENCE}

CC BY-NC-ND 4.0

\section{REPOSITORY RECORD}

Peiris, Sujanie, Bruce Corben, Michael Nieuwesteeg, Hampton C. Gabler, Andrew Morris, Di Bowman, Michael G. Lenne, and Michael Fitzharris. 2019. "Evaluation of Alternative Intersection Treatments at Rural Crossroads Using Simulation Software". figshare. https://hdl.handle.net/2134/35944. 


\section{AUTHORS}

Sujanie Peiris ${ }^{a}$, Bruce Corben ${ }^{b}$, Michael Nieuwesteeg ${ }^{c}$, Hampton C. Gabler $^{\mathrm{d}}$, Andrew Morris ${ }^{\mathrm{e}}$, Diana Bowman $^{f}$ Michael G. Lennéa, and Michael Fitzharris ${ }^{a}$

\section{AFFILIATIONS}

a Accident Research Centre, Monash University, Melbourne, Australia

${ }^{\mathrm{b}}$ Corben Consulting, Australia

c Transport Accident Commission, Victoria, Australia

${ }^{\mathrm{d}}$ Center for Injury Biomechanics, Virginia Tech, USA

e Design School, Loughborough University, United Kingdom

${ }^{\mathrm{f}}$ Sandra Day O'Connor, Arizona State University, Phoenix, Arizona

\section{COMPLETE MAILING AND EMAIL ADDRESS}

Sujanie Peiris

Accident Research Centre

Monash University

Victoria, Australia 3800

Sujanie.Peiris@,monash.edu

\section{Bruce Corben}

Corben Consulting

Melbourne, Victoria, Australia

bruce@corbentrafficsafety.com.au

\section{Michael Nieuwesteeg}

Transport Accident Commission, Geelong, Victoria, Australia.

Michael_Nieuwesteeg@tac.vic.gov.au

\section{Hampton C. Gabler}

Center for Injury Biomechanics

Virginia Tech, Blacksburg, Virginia, USA.

gabler@,vt.edu

\section{Andrew Morris}

Design School, Loughborough University

Loughborough, United Kingdom.

A.P.Morris@lboro.ac.uk

\section{Diana Bowman}

Sandra Day O'Connor College of Law

Arizona State University, Arizona, USA

Diana.Bowman@asu.edu 
Michael G. Lenné

Accident Research Centre

Monash University

Victoria, Australia 38

Michael.Lenne@monash.edu

Michael Fitzharris

Accident Research Centre

Monash University

Victoria, Australia 3800

Michael.Fitzharris@monash.edu

KEYWORDS: Reconstructions, roundabout, countermeasures, speed reduction, rural 


\section{ABSTRACT}

Objective: Rural roads are characterised by hazardous roadsides and suboptimal geometry, yet allow for high travel speeds and unfavourable impact angles. In Victoria, $25 \%$ of persons seriously injured and $52 \%$ of fatalities occur on rural roads, with 30\% occurring at intersections (Transport Accident Commision, 2016; Victorian Parliament Road Safety Committee 2002). In the USA, almost twice the number of traffic fatalities occur in rural areas than in urban areas, whilst accounting for less than half of all vehicle miles travelled and $21 \%$ of the population (NHTSA 2002). The choice of safety countermeasure is therefore paramount. Simulation software provides a cost-effective means of analysing alternative intersection treatments with a view to identifying their effectiveness in mitigating crashes. The aim of this research was to assess the safety benefits of four alternative intersection treatments using in-depth crash data with an advanced crash reconstruction process.

Method: Using a single serious injury real-world crash from the MUARC Enhanced Crash Investigation Study (ECIS, Fitzharris et al., 2015) and crash reconstruction software, an exemplar rural crash was reconstructed and validated against real-world data. The crash involved a passenger vehicle (EuroNCAP $5^{*}$ ) approaching from a minor road and failing to yield at a 'give-way' sign; the posted speed limit was $80 \mathrm{~km} / \mathrm{h}$. The vehicle was struck on the right/driver side by a rigid truck (B-vehicle; 1990) travelling on the major approach (100 km/h). The driver of the case vehicle was seriously injured. Four alternative intersection treatments appropriate for the crash site were constructed in CAD software (Rhinoceros V5): roundabout; rumble strips; a reduced speed limit and the combination of lower speed limit and rumbles to determine the reduction in crash forces in the presence of the countermeasures.

Results: The hypothetical scenarios demonstrate substantial reductions in impact force and different points of impact, resulting in a significantly lower injury severity for the struck driver. Speed limit reduction to $80 \mathrm{~km} / \mathrm{h}$ on the main approach (from $100 \mathrm{~km} / \mathrm{h}$ ) in combination with rumble strips on both intersection approaches had the most favorable outcome with the crash avoided entirely, assuming speed compliance.

Discussion: The findings have implications for understanding the role of speed in crashes, and hence the design of effective countermeasures. Simulation software, validated using real-world data, provides a cost effective means of evaluating alternative intersection treatments for rural intersections. Scaled up, implementing these treatments would have significant safety benefits and reduce the road trauma currently associated with rural roads. 


\section{INTRODUCTION}

Intersections are particularly hazardous sections of road for vehicles to navigate. Vehicle trajectories cross at these sites exposing drivers to 32 potential conflict points at a typical four-legged intersection or nine potential conflict points at a three-legged intersection. In high-income countries intersection crashes are the location of the third most frequent source of road-trauma related death and serious injury, followed by head-on crashes and run off road crashes (World Road Association 2003). Rural intersections are particularly dangerous as crashes at these sites typically result in a high level of injury as they frequently occur at high speeds and at unfavourable impact angles, where side impact crashes are common.

Global statistics, including those from the USA and Europe show that intersection-related crashes with a fatal outcome represent approximately $20 \%$ of all traffic fatalities (Sunnevång et al. 2011). During 2015 in the USA, $47 \%$ of all crashes (fatal, injury and property damage) recorded in Fatality Analysis Reporting System (FARS) and National Automotive Sampling System-General Estimates System (NASS-GES) were intersection-related crashes (NHTSA, 2015). Over $40 \%$ of these intersection crashes were at an unsignalised intersection. In human terms, this translates to 13,846 individuals killed at an intersection with 8,570 individuals (62\%) traversing an unsignalised intersection (NHTSA 2015).

The scenario is similar in Australia, where approximately one-third of all serious casualty crashes occur at intersections, whilst in Victoria approximately $45 \%$ of serious casualty crashes and $20-30 \%$ of fatalities occur at intersections (Candappa et al. 2015; Hoareau et al. 2011). The high financial cost associated with intersection crashes is well recognised. Using Australian fatality data, in the period 2001 to 2006, side impact crashes, including those occurring at intersections cost \$AU 5.87 billion (Fitzharris and Stephan 2013). Fitzharris and Stephens (2013) also used UK Co-operative Crash Injury Study (CCIS) data to show that $88 \%$ of all side impact crashes were vehicle-to-vehicle impacts and the severity of injury was high.

Rural intersections present a particular challenge to road safety agencies due to their high number across the road and frequently low traffic volumes. Controlled only by Stop or Give-Way signs, drivers at unsignalised intersections are given no objective indication of when it is safe to enter the intersection, other than requiring compliance with the traffic signal. The inherent danger of un-signalised intersections is further compounded by the complexities associated with the failure to assess the speed of major roadway vehicles and misjudgement of gap has been demonstrated to be one of the most common reasons for crashes at un-signalised intersections (Braitman et al. 2007; Choi 2010; Schepers et al. 2011; Stokes et al. 2000). This is accentuated for drivers unfamiliar with the specific environment. From a behavioural compliance perspective, a failure to yield to right of way traffic and distraction-related causes are the two most frequent violations implicated with poor decision making leading to crashes in these locations (Nitsche et al. 2017; Sandin 2009).

The safety at an unsignalised intersection is also influenced by traffic volume (and speed of traffic) on the major road in addition to the presence of yield signs. Characteristics such as road geometry, the configuration of the intersection, number of right and/or left turn lanes, median type on the major road, and left and right shoulder widths have all been shown to influence crash risk (Haleem et al. 2010). Hence, intersection design can play a critical role not only in its conspicuity but also in influencing driver behaviour and actions.

Given the above, it is of value to identify cost-effective countermeasures that can act to prevent intersection crashes or act to mitigate the severity of injury in the event crashes occur at these cross roads. Speed reduction 
interventions that can be introduced at intersections are likely to have a positive influence on road safety and is reflective of safe system thinking. Interventions may include physical realignment of the entire intersection, grade separation or other methods such as perceptual countermeasures and visual warning systems (Woolley et al. 2018).

An example of an infrastructure design that promotes safety whilst ensuring high levels of mobility are roundabouts. Roundabouts are gaining popularity globally for their safety, capacity, and environmental benefits as a solution at unsignalised intersections (Sadeq and Sayed 2016; Woolley et al. 2018). Studies by the IIHS and Federal Highway Administration have shown that roundabouts typically achieve a 37\% reduction in overall collisions. Reductions as high as $90 \%$ for fatality collisions and $75 \%$ for injury crashes where stop signs or signals were previously used for traffic control have been reported (Washington State Department of Transport 2018). These findings are consistent with evaluations of the installation of roundabouts in Australia, with research showing a 70\% reduction in fatal and serious crash outcome when a roundabout (Bureau of Transport Economics, 2001) replaces sign-controlled intersections. Similarly, in Victoria, roundabouts have been associated with a minimum $37 \%$ reduction in severe injury crashes and $60 \%$ reduction in fatality crashes, with higher reductions also observed at specific sites (Woolley et al. 2018).

By altering vehicle trajectories, roundabouts induce a reduction in intersection entry speeds, and by extension, so too are impact speeds reduced; impact angles are also changed in the event of a collision. It is not however practical for all intersections to be redesigned and rebuilt. It is thus of value to assess a range of other countermeasures, including low cost measures, that could be applied to intersections and to assess their likely benefit. Combining in-depth data collection with innovative computer-based crash reconstruction methods provides a cost-effective way to achieve this goal.

The use of crash simulation software and real-world crash data to reconstruct real-world crashes in order to study crash forces and occupant kinematics is well established (Franklyn et al. 2005; Menon et al. 2003; Peiris et al. 2015). Vehicle damage and crash severity estimates, vehicle trajectories, impact- and rest-positions, along with case narratives and police reports have previously been used to reconstruct crashes in software such HVE or PC-Crash to obtain outputs such as acceleration pulses and impact severity measures, such as delta-V (Gabler et al. 2003; Richardson et al. 2015; Simionescu and Preda 2016).

With reference to crash reconstruction outputs (i.e., crash forces, delta- $\mathrm{V}$ and impact angles), the effectiveness of road layouts, infrastructure, and alternative intersection treatments can be quantified. Once a crash is validated within the reconstruction software, road features can be varied to gain a better understanding of how the vehicles would behave to a given input or obstacle; that is, what would be the effect of a change in an input parameter on the crash severity metrics? This is the essence of applying an 'alternative scenario'.

Given the above, the aim of this study was to assess the likely impacts of three infrastructure countermeasures on crash severity metrics. Having first established a valid crash reconstruction for a high speed rural intersection crash, the influence of installation of a roundabout, a speed limit reduction, and the influence of rumble strips on the intersection approach on crash severity metrics was examined. The aim of this study is to examine the potential road safety benefits of three road infrastructure interventions on crash and injury risk at an exemplar un-signalised intersection using a novel application of crash reconstruction methods. 


\section{METHODS}

\section{Study Data}

The Enhanced Crash Investigation Study (ECIS) is a large-scale retrospective case-control study conducted at the Monash University Accident Research Centre (MUARC) and was sponsored by the Victorian Transport Accident Commission (TAC). The ECIS seeks to document the causes and consequences of 400 serious injury crashes in Victoria. The goal of the study is to identify effective road safety countermeasures that are directly relevant to the crash problem observed.

The reader is referred to Fitzharris et al., (2015) for a detailed outline of the ECIS data collection protocol. In brief, ECIS Research Nurses seek consent and participation from drivers or their next-of-kin when drivers are admitted following an injurious crash to one of two major trauma hospitals in Melbourne. Relevant medical data, ambulance notes and police reports are obtained. Injuries to the case driver are coded as per AIS 2005 by Research Nurses trained in the AIS system (AAAM 2005). Trained technical staff then inspect the crashed vehicle(s) and the crash scene, collecting vehicle damage measures, vehicle data, Event Data Recorder modules (when available), scene information and crash evidence. All evidence is used to perform crash reconstructions as well as establishing contributing factors for the occurrence of the crash.

For the study here, one real-world serious injury crash that occurred at an un-signalised cross-intersection is used.

\section{Case study details}

The crash occurred at a rural un-signalised intersection approximately $300 \mathrm{~km}$ (186 miles) outside of Melbourne (capital city), Victoria (Australia).

The crash occurred in mid-afternoon in clear conditions and involved a young female driver of a late-model light passenger vehicle that had a 5-star vehicle safety rating; two other passengers were present.

The case vehicle was travelling on a secondary state arterial with a posted speed limit of $80 \mathrm{~km} / \mathrm{h}$. The case driver failed to yield at a Give Way sign and was struck on the right (driver) side by a medium size rigid truck that was travelling on the principal carriageway $(100 \mathrm{~km} / \mathrm{h}$ speed limit). This can be seen in Figure 1.

The case vehicle driver sustained an AIS 5 chest injury (tension pneumothorax), two AIS 3 chest injuries and several AIS 2 and AIS 1 injuries to the face, stomach, chest and head (AIS 2005). The case vehicle driver held a (full, car) licence. A lack of familiarity with the intersection and poor intersection geometry were implicated with driver error. In addition to the case vehicle driver being admitted to a major trauma centre, both passenger occupants also required hospitalisation for injuries sustained. The non-case vehicle driver sustained minor injuries and did not require admission to hospital. This was the only recorded crash at this location in the period $2012-2016$

Insert Figure 1 here.

\section{Software and Reconstruction}

Using available inputs, a crash reconstruction was performed using the Simulation Model Non-Linear (SIMON) application within Human Vehicle Environment (HVE, V11.2). Vehicles which most closely represented the 
real-world vehicles were chosen from HVE (since exact Australian makes and models were unavailable). Once a representative vehicle was selected, parameters such as the drive axle location, driver location and vehicle weight were all adjusted to match the real-world vehicle.

The crash site was generated in Rhinoceros V5 using Nearmap satellite imagery and imported into the HVE program with appropriate friction factors assigned ( 0.8 for the asphalt, 0.7 for the grass).

\section{Study Design \\ Crash validation}

The case vehicle was represented by a 'like' vehicle while the rigid truck was represented by a rigid van with similar geometry and mass to the actual truck (1996-2006 GMC 15-Foot Box Van, 10,000kg). The selected vehicle was weight-matched to the truck involved in the crash.

The case vehicle and B-vehicle driver input parameters (steering, throttle and brakes) were varied until the crash reconstruction was validated against the narrative and the vehicles' rest positions (see Appendix 1, Figure 1 and Figure 2).

No EDR data was available. The crash reconstruction suggested that the case vehicle driver was likely to have been travelling above the speed limit (initial speed $94.5 \mathrm{~km} / \mathrm{h}, 2.38 \mathrm{~s}$ prior to impact) and both drivers braked heavily pre-crash. The driver's injuries are consistent with a high-speed side impact. In generating the reconstruction scenarios, it was assumed that the case vehicle driver would be compliant with the speeds and countermeasures.

\section{Modelled alternative scenarios: implementing three alternative infrastructure interventions}

Three speed reduction countermeasures were assessed and their effect in reducing impact forces were quantified. The combined effect of a lower speed limit plus rumble strips was also examined. These countermeasures were:

\section{Installation of a roundabout}

A hypothetical roundabout ( $7 \mathrm{~m}$ diameter) was generated in Rhinoceros V5.0 and placed centrally in the original reconstruction of the crash site. Vehicles speed were gradually decreased and steering inputs varied until the vehicles were able to navigate through the roundabout. The crash was simulated at the highest speed at which the case and B-vehicle could navigate through the roundabout.

\section{Reduced speed limit from $100 \mathrm{~km} / \mathrm{h}$ to $80 \mathrm{~km} / \mathrm{h}$ on the principal road}

This requires acceptance of the assumption that if the posted speed limit was reduced from $100 \mathrm{~km} / \mathrm{h}$ to $80 \mathrm{~km} / \mathrm{h}$ then the trucks approach speed would be reduced by $20 \mathrm{~km} / \mathrm{h}$; that, vehicles would be speed limit compliant. Initial speed refers to the driver's speed $2.38 \mathrm{~s}$ prior to impact. Test track data has shown that average reaction time is approximately $2.3 \mathrm{~s}$ from the point at which the driver begins to release the accelerator pedal up to the maximum brake application point (McGehee et al. 2000). It was assumed the B-vehicle driver was not cognitively impaired and was travelling at free-speed at $2.38 \mathrm{~s}$ pre-impact, and at the revised $80 \mathrm{~km} / \mathrm{h}$ speed limit. 


\section{Installation of rumble strips on both approaches.}

Rumble strips were generated in Rhinoceros V5 and placed $200 \mathrm{~m}$ away from the intersection on both approaches. The use of rumble strips and driver reactions have not been validated using HVE previously. Therefore, an assumption was made that a $6.4 \mathrm{~km} / \mathrm{h}$ speed reduction would be achieved in the presence of rumble strips placed 200 metres prior to the intersection (as per research by (Hore-Lacy 2008; Thompson et al. 2006). Vehicle speeds were reduced accordingly at that point of commencement of the rumble strips.

\section{Combined $80 \mathrm{~km} / \mathrm{h}$ (main road) plus rumble strips.}

An $80 \mathrm{~km} / \mathrm{h}$ speed limit was applied to both approaches and it was assumed that rumble strips were placed 200 $\mathrm{m}$ away from the intersection so a speed reduction of $6.4 \mathrm{~km} / \mathrm{h}$ would be achieved. The reconstruction was performed with the drivers approaching the intersection at speeds of $73.6 \mathrm{~km} / \mathrm{h}$ (case vehicle) and $74.6 \mathrm{~km} / \mathrm{h}$ (truck) respectively.

\section{RESULTS}

\section{Travel speed and impact speed metrics}

The outcomes for the original crash and the four hypothetical scenarios are presented in Table 1 and Table 2 for the case vehicle driver and B-driver respectively. The original crash scenario reconstruction indicated an initial speed of $94.5 \mathrm{~km} / \mathrm{h}$ and an impact speed of $57.3 \mathrm{~km} / \mathrm{h}$ with the impact point being the driver side door. The Bvehicle pre-crash travel speed was $101 \mathrm{~km} / \mathrm{h}$, the impact speed was $82.7 \mathrm{~km} / \mathrm{h}$ and the impact point was the left front panel.

Application of the alternative scenarios highlights pre-crash travel speed reductions, lower impact speed and an altered impact point. Figure 2 and Figure 3 highlight the difference in impact point to the case vehicle in the original crash compared to when a speed reduction is applied on the major road (Appendix 1, Figure 3-Figure 5 presents the points of impact to the case vehicle and B-vehicle for the other alternative treatments).. The differences in impact speed, impact angle and impact point are important as they would more than likely result in lower injury severity (which was not explicitly assessed). While the reduction of the speed limit from 100 $\mathrm{km} / \mathrm{h}$ to $80 \mathrm{~km} / \mathrm{h}$ plus the installation of rumble strips on all intersection approaches would result in lower speeds such that the impact was avoided, the installation of a roundabout resulted in the highest reduction in impact speed (-69.5\%, B-vehicle), followed by a reduction in the speed limit alone (-39\%, B-vehicle) and rumble strips alone (-6.3\%, B-vehicle). In this case, B-vehicle speeds are noted as it acts as the bullet vehicle, but the case vehicle speeds are also reduced, resulting in a different location of impact and associated PDOF. In addition to the reductions in impact speed, this also translates to reductions in force and kinetic energy. On the point of differential impact location on the case vehicle, of note was the alternate crash outcome associated with the rumble strip only countermeasure option where the impact would be a frontal impact into side of truck, this being a more favorable impact (assuming no under-run) than a pure driver-side impact.

Insert Table 1 here.

Insert Table 2 here.

Insert Figure 2 here. 
Insert Figure 3 here.

\section{Kinetic Energy Measures}

The kinetic energy prior to the point of impact was derived for both vehicles (Table 3). Kinetic energy is a function of speed and therefore is proportional to the velocity at which the vehicles are travelling. It is therefore not surprising that the kinetic energy was lowest for both vehicles prior to impact at the roundabout, since the largest speed reduction was achieved by this countermeasure, noting however that the impact was avoided in the fourth scenario.

Insert Table 3 here.

\section{DISCUSSION}

This study set out to examine the potential road safety benefits of three road infrastructure interventions on crash and injury risk at an exemplar un-signalised intersection using a novel application of crash reconstruction methods. This aim was motivated by the known high risk that these intersections pose and the need for effective countermeasures to mitigate crash and injury risk.

In the original case, the case vehicle driver (age category 25-29 years; seat-belt worn) sustained critical rightside chest injuries due to intrusion associated with a near-side truck impact. The driver also sustained fractured facial bones (moderate severity) and a minor head laceration due to contact with internal vehicle structures. The late model light passenger vehicle, rated as a 5-star EuroNCAP vehicle, was equipped with a side curtain airbag that deployed. The collision partner (rigid truck) was travelling at the posted speed limit and the driver braked beforehand. That the case vehicle driver sustained minor head injuries points to the effectiveness of the side curtain airbag, although the driver sustained multiple severe chest injuries. Given the high impact speed -hence high kinetic energy, and poor impact geometry, the injury outcomes to the chest and pelvis can be anticipated. As noted in the Introduction, it is precisely these types of impacts at uncontrolled high-speed intersections that are associated with a large number of deaths and serious injuries. The purpose of this research was to assess the likely effect of three alternative infrastructure changes, with a further combined intervention of lower speed limit plus site-specific rumble strips. Whilst assumptions are made about the speed reduction effectiveness of these measures and driver compliance, the findings demonstrate that each of the interventions resulted in sizeable reductions in impact speed, translating to lower kinetic energy from which injury is a product (Campbell 1974; Sobhani et al. 2011).

Of the interventions assessed, the combined $20 \mathrm{~km} / \mathrm{h}$ speed limit reduction (from $100 \mathrm{~km} / \mathrm{h}$ to $80 \mathrm{~km} / \mathrm{h}$ ) plus rumble strips on all approaches resulted in the most optimal outcome, with the impact being avoided entirely. For scenarios where the impact occurred, the installation of the roundabout provided the highest impact and force reductions (B-vehicle impact speed: $-69.5 \%$; A/B vehicle force: $-82 \%$ ), followed by the reduced speed limit alone (B-vehicle impact speed: $-39.2 \% ; \mathrm{A} / \mathrm{B}$ vehicle force: $-53 \%$ ), and then the installation of rumble strips alone (B-vehicle impact speed: $-12.9 \%$; A/B vehicle force: $-64 \%$ ). We note the B-vehicle impact speed as it acts as the bullet vehicle, although the speed at which the case vehicle is travelling pre-crash and at impact is also reduced. The kinetic energy of the crash is reduced significantly and is reflective of the same order of interventions. 
The results of the hypothetical scenarios demonstrate substantial reductions in impact force and different points of impact, noting assumptions are made about the adherence of drivers to the scenarios. These reductions can be expected to translate to significantly lower injury severity for the driver. Translation of these revised force values into the probability of injury is an important next step in this research, as is the monetisation of the benefits to the community.

While only a single case study is examined here, the findings are a powerful way to examine the benefits of three infrastructure interventions. The crash, the only one in this location in the 5-year period (2012-2016), represents an 'index case' for how 'like' crashes can be either eliminated or the injury severity mitigated.

Based on these findings, intersection designs that require drivers to reduce speed are likely to bring significant road safety benefits. We note that subject to community acceptance, a localised reduction in the speed limit represents the single most cost-effective intervention of those examined here, with added benefit from the addition of rumble strips to the point that the collision studied would likely be avoided entirely. Rumble strips alone was also seen to bring road safety benefits albeit lower than the other interventions examined. Whilst roundabouts are shown to be associated with the highest reduction in kinetic energy given that an impact occurs, they do represent a more expensive approach than a reduction in the speed limit alone.

In presenting these findings we appreciate that while blanket speed reductions across road networks can be difficult to implement. Hence, reducing travel speeds on approach to intersections by using Rural Intersection Active Warning Systems (RIAWS) is likely to have significant safety gains (Mackie et al. 2015) and are more likely to be acceptable to the community as location-based risk can be directly acknowledged by drivers. Whilst not examined, the installation of a 2-way or 4-way stop sign in place of a 'give-way' sign offers a further alternative.

Translation of the findings here into practice requires an understanding of the broader crash problem as well as site specific considerations. However, following best practice safe system principles, route-based treatments are preferable to a single site treatment approach. Analysis of crash data indicated that in the same period there were 190 crashes where a vehicle entered a $100 \mathrm{~km} / \mathrm{h}$ or $110 \mathrm{~km} / \mathrm{h}$ highway or freeway in the same manner as the case reported here, resulting in 11 deaths and 139 persons hospitalised, with the cost of these injuries using standard estimates (Fitzharris \& Stephan, 2013) being \$AUD 313.4 million, at an average cost per crash being \$AUD 1.649 million. These crashes occurred on $24(100 \mathrm{~km} / \mathrm{h})$ and $6(110 \mathrm{~km} / \mathrm{h})$ rural routes. It is likely that there are many other 'like' intersections where crashes have either not occurred, or have but fall outside of the 5-year period. Indeed, extending the crash period from 2006 to 2016 increases the number of 'like' crashes to 568 at an economic cost of \$AUD 741.8 million.

While not all rural intersections may warrant high-cost countermeasures such as roundabouts, our findings highlight the crash and injury reduction benefits of low cost interventions including localised speed limit reductions, substitution of traffic signs and perceptual countermeasures. Given the nature of the crash problem described above, the judicious use of appropriate treatments along routes is likely to be cost-effective. We do however acknowledge that a comprehensive route-based analysis needs to be undertaken to ensure appropriate decisions are made. 
In sum, this study provides important findings regarding the likely effectiveness of infrastructure interventions, that when applied locally and across the road network, would be expected to bring considerable benefit by reducing lives lost and avoiding serious injuries in these road locations. In addition this study also demonstrates the value of real-world crash data and crash reconstruction methods in evaluating the likely benefits of alternative intersection designs. Further work ought to be undertaken using a wider range of crash environments and road safety countermeasures.

\section{ACKNOWLEDGMENTS}

The authors acknowledges the funding and logistical support provided by the Victorian Transport Accident Commission (TAC). In particular, the authors wish to thank Michael Nieuwesteeg and Samantha Cockfield for their support and Renee Shuster (TAC) and Jacinta Evans (TAC) for assistance in the control arm of the program.

The authors also wish to acknowledge the ECIS Investigator team and the ECIS study team for contributions to the broader ECIS program and data collection activity. In addition to the ECIS Investigators, current members of the ECIS team are Tandy Pok Arundell, Tom Behrendt, Daniel Machell, Anna Magennis, Natalie Seeto and Russell Phoung. 


\section{REFERENCES}

AAAM. Abbreviated Injury Scale (AIS) 2005. Chicago, IL: Association for the Advancement of Automotive Medicine. 2005.

Braitman KA, Kirley BB, Ferguson S, Chaudhary NK. Factors leading to older drivers' intersection crashes. Traffic injury prevention. 2007;8(3):267-274.

Bureau of Transport Economics (2001). The Black Spot Program 1996-2002: An evaluation of the first three years. Canberra, ACT 2601, Bureau of Transport Economics, 104: pp 254

Campbell KL. Energy basis for collision severity. SAE Technical Paper. 1974. 0148-7191.

Candappa N, Logan D, Van Nes N, Corben B. An exploration of alternative intersection designs in the context of Safe System. Accident Analysis \& Prevention. 2015;74:314-323.

Choi, E. (2010). Crash Factors in Intersection-Related Crashes: An On-Scene Perspective. US DOT National Highway Traffic Safety Administration. Washington, DC NHTSA. DOT HS 811 366:1- 37

Fitzharris M, Stephan MK. Assessment of the need for, and the likely benefits of, enhanced side impact protection in the form of a Pole Side Impact Global Technical Regulation. Monash University Accident Research Centre, Melbourne, Victoria. Accessed 15th August, 2017; 2013:pp 219.

Fitzharris, M., et al. (2015). The MUARC-TAC enhanced crash investigation study: a platform to understand the causes and consequences of serious injury crashes. Proceedings of the 2015 Australasian Road Safety Conference, Gold Coast, Australia, 14th - 16th October, 2015.

Franklyn M, Logan D, Hillard P, Fildes B. Full crash test reconstruction and analysis of four real-world impacts. Paper presented at: Australasian Road Safety Research Policing Education Conference, 2005, Wellington, New Zealand. 2005.

Gabler HC, Hampton C, Roston T. Estimating crash severity: can event data recorders replace crash reconstruction? Paper presented at: Proceedings: International Technical Conference on the Enhanced Safety of Vehicles. 2003.

Haleem K, Abdel-Aty M, Mackie K. Using a reliability process to reduce uncertainty in predicting crashes at unsignalized intersections. Accident Analysis \& Prevention. 2010;42(2):654-666.

Hoareau E, Candappa N, Corben B (2011). Intersection Study Task 1 Report. Melbourne, Victoria, Monash University Accident Research Centre. Report No. 316a: 1-146..

Hore-Lacy W. Rumble strip effectiveness at rural intersections and railway level crossings. Vermont South, Victoria: ARRB Group; 2008.

Mackie H, Scott R, Hawley G. Rural Intersection Active Warning System (RIAWS) Trial, Final Report. Retrieved from NZ Transport Agency. Wellington, New Zealand; 2015.

McGehee DV, Mazzae EN, Baldwin GS. Driver reaction time in crash avoidance research: Validation of a driving simulator study on a test track. Paper presented at: Proceedings of the human factors and ergonomics society annual meeting. 2000.

Menon RA, Ghati YS, Marigowda SB, Arbogast KB, Winston FK. Reconstruction of Real World Side Impact Vehicle Collisions Using HVE-A Case Series of Pediatric Pelvic Fracture. Paper presented at: HVE Forum2003.

NHTSA. Traffic Safety Facts 2015: A Compilation of Motor Vehicle Crash Data from the Fatality Analysis Reporting System and the General Estimates System. Washington, DC 20590: National Highway 
Traffic Safety Administration, Administration National Center for Statistics and Analysis, U.S.

Department of Transportation;2015.

Nitsche P, Thomas P, Stuetz R, Welsh R. Pre-crash scenarios at road junctions: a clustering method for car crash data. Accident Analysis \& Prevention. 2017;107:137-151.

Peiris S, Arundell T, Gabler H, Curry R, Fitzharris M. The MUARC-TAC Enhanced Crash Investigation Study: Using Event Data Recorders and Simulated Crash Reconstructions in the Analysis of Crash Causation. Paper presented at: Australasian Road Safety Conference 2015; Gold Coast, Queensland, Australia.

Richardson S, Moser A, Orton TL, Zou R. Simulation of vehicle lateral side impacts with poles to estimate crush and impact speed characteristics. SAE Technical Paper. 2015; 0148-7191.

Sadeq H, Sayed T. Automated roundabout safety analysis: diagnosis and remedy of safety problems. Journal of Transportation Engineering. 2016;142(12):04016062.

Sandin J. An analysis of common patterns in aggregated causation charts from intersection crashes. Accident Analysis \& Prevention. 2009;41(3):624-632.

Schepers J, Kroeze P, Sweers W, Wüst J. Road factors and bicycle-motor vehicle crashes at unsignalized priority intersections. Accident Analysis \& Prevention. 2011;43(3):853-861.

Simionescu PA, Preda I. Example of a High-Speed, Side-Impact, Car Crash Reconstruction Using a Planar Multibody Software. Paper presented at: International Congress of Automotive and Transport Engineering. 2016.

Sobhani A, Young W, Logan D, Bahrololoom S. A kinetic energy model of two-vehicle crash injury severity. Accident Analysis \& Prevention. 2011;43(3):741-754.

Fitzharris M, Stephan K. Assessment of the need for, and the likely benefits of, enhanced side impact protection in the form of a Pole Side Impact Global Technical Regulation. Monash University, 2013 http://www.infrastructure.gov.au/roads/publications/files/PSI_GTR_Report.pdf

Stokes RW, Rys MJ, Russell ER, Robinson RK, Budke B. Analysis of Rural Intersection Accidents Caused by Stop Sign Violation and Failure to Yield the Right-of-Way. Kansas Department of Transportation, Manhattan, Kansas; 2000.

Sunnevång C, Boström O, Lie A, Stigson H. Census study of fatal car-to-car intersection crashes in Sweden involving modern vehicles. Traffic injury prevention. 2011;12(4):333-338.

Transport Accident Commission (2016). "Making rural roads safer." Towards Zero: making progress. Retrieved 5 September, 2016, from https://www.towardszero.vic.gov.au/news/articles/Making-rural-roads-safer.

Thompson T, Burris M, Carlson P. Speed changes due to transverse rumble strips on approaches to high-speed stop-controlled intersections. Transportation Research Record: Journal of the Transportation Research Board. 2006; 1973:1-9.

Victorian Parliament Road Safety Committee Rural road safety and infrastructure : report of the Road Safety Committee on the Inquiry into rural road safety and infrastructure. Victorian Government Printer, Melbourne, Victoria, 2002;2002.

Washington State Department of Transport Roundabout benefits. 2018; https://www.wsdot.wa.gov/Contact/default.htm. Accessed 27 March, 2018.

Woolley J, Stokes C, Turner B, Jurewicz C. Towards Safe System Infrastructure: A Compendium of Current Knowledge. Sydney, Australia: Austroads Ltd.; 2018. 
World Road Association Road Safety Manual - World Road Association. Permanent International Association of Road Congresses (PIARC) Technical Committee on road safety; 2003. 


\section{FIGURES}

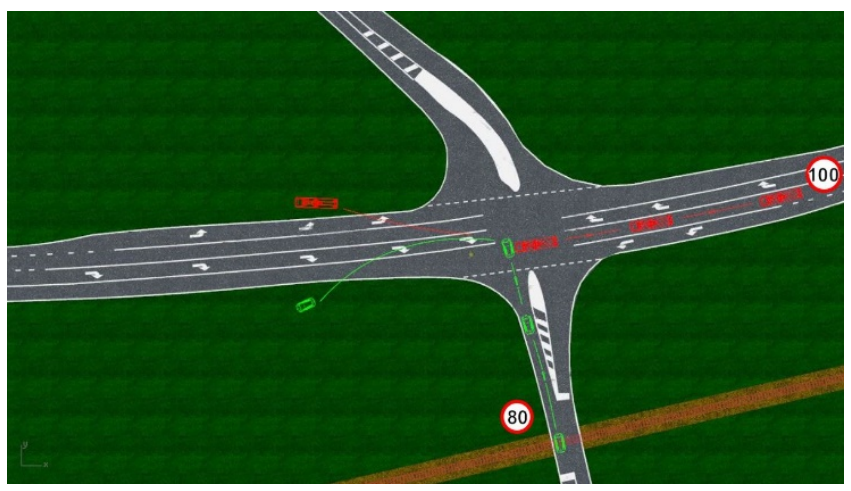

Figure 1. A schematic of the crash and post-impact vehicle locations (case vehicle: green; B-vehicle: red) 


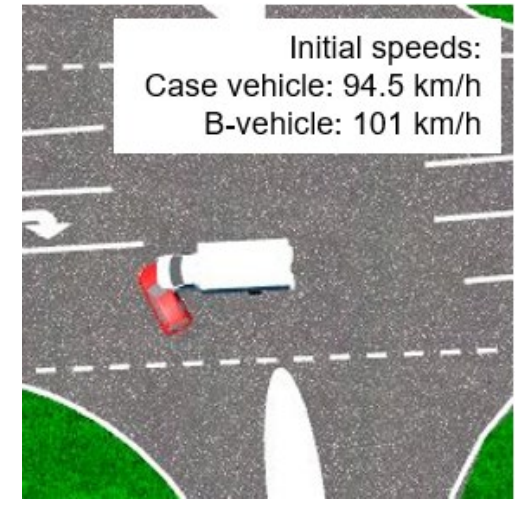

Figure 2. Simulation still showing the point of impact between the case vehicle (red) and B-vehicle (truck) from the original crash reconstruction. 


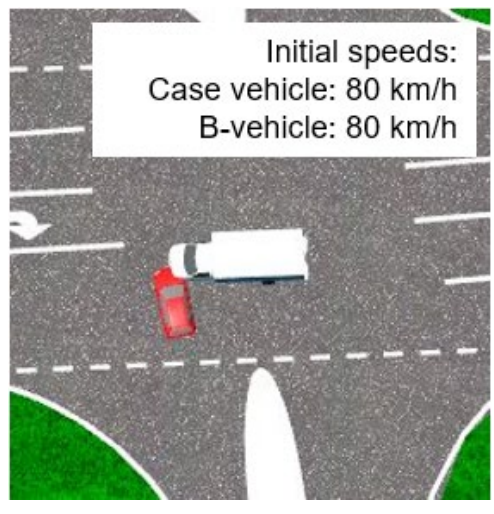

Figure 3. Simulation still showing point of impact between the case vehicle (red) and B-vehicle (truck) when the major approach is signed at $80 \mathrm{~km} / \mathrm{h}$. 


\section{TABLES}

Table 1. Case vehicle specifics - Simulated crash outcomes with alternative intersection designs (percent change from original scenario)

\begin{tabular}{|c|c|c|c|c|c|c|}
\hline Scenario & $\begin{array}{l}\text { Initial } \\
\text { velocity } \\
(\mathbf{k m} / \mathbf{h})\end{array}$ & $\begin{array}{l}\text { Impact } \\
\text { velocity } \\
(\mathbf{k m} / \mathbf{h})\end{array}$ & $\begin{array}{l}\text { Delta-V } \\
(\mathrm{km} / \mathrm{h})\end{array}$ & $\begin{array}{l}\text { Impact } \\
\text { point }\end{array}$ & PDOF $\left(^{\circ}\right)$ & $\begin{array}{l}\text { Force } \\
\text { (N) }\end{array}$ \\
\hline $\begin{array}{l}\text { Original crash } \\
\text { (Case study, } \\
\text { validated) }\end{array}$ & 94.5 & 57.3 & 101.2 & $\begin{array}{l}\text { Driver-side } \\
\text { door }\end{array}$ & 71.7 & 597,808 \\
\hline Roundabout & $\begin{array}{l}54 \\
(-42.8 \%)\end{array}$ & $\begin{array}{l}44.4 \\
(-22.5 \%)\end{array}$ & $\begin{array}{l}19.1 \\
(-81.1 \%)\end{array}$ & $\begin{array}{l}\text { Right B- } \\
\text { pillar/RHS } \\
\text { Rear } \\
\text { Passenger } \\
\text { door }\end{array}$ & 51.3 & $\begin{array}{l}104,255 \\
(-82.5 \%)\end{array}$ \\
\hline $\begin{array}{l}\text { Reduced speed } \\
\text { limit main } \\
\text { road }\end{array}$ & $\begin{array}{l}80 \\
(-15.3 \%)\end{array}$ & $\begin{array}{l}45.3 \\
(-20.9 \%)\end{array}$ & $\begin{array}{l}53.7 \\
(-46.9 \%)\end{array}$ & $\begin{array}{l}\text { Right front } \\
\text { panel/front } \\
\text { tyre }\end{array}$ & 45.8 & $\begin{array}{l}281,257 \\
(-52.9 \%)\end{array}$ \\
\hline Rumble strips & $\begin{array}{l}88.1 \\
(-6.7 \%)\end{array}$ & $\begin{array}{l}41.3 \\
(-27.9 \%)\end{array}$ & $\begin{array}{l}54.1 \\
(-46.5 \%)\end{array}$ & $\begin{array}{l}\text { Frontal } \\
\text { impact }\end{array}$ & 40 & $\begin{array}{l}215,659 \\
(-63.9 \%)\end{array}$ \\
\hline $\begin{array}{l}\text { Reduced speed } \\
\text { limit main } \\
\text { road plus } \\
\text { rumble strips }\end{array}$ & $\begin{array}{l}73.6 \\
(-22.1 \%)\end{array}$ & $\begin{array}{l}\text { Impact } \\
\text { avoided }\end{array}$ & $\begin{array}{l}\text { Impact } \\
\text { avoided }\end{array}$ & $\begin{array}{l}\text { Impact } \\
\text { avoided }\end{array}$ & $\begin{array}{l}\text { Impact } \\
\text { avoided }\end{array}$ & $\begin{array}{l}\text { Impact } \\
\text { avoided }\end{array}$ \\
\hline
\end{tabular}


Table 2. B-vehicle specifics - Simulated crash outcomes with alternative intersection designs (percent change from original scenario shown)

\begin{tabular}{|l|l|l|l|l|l|l|}
\hline Scenario & $\begin{array}{l}\text { Initial } \\
\text { velocity } \\
(\mathbf{k m} / \mathbf{h})\end{array}$ & $\begin{array}{l}\text { Impact } \\
\text { velocity } \\
(\mathbf{k m} / \mathbf{h})\end{array}$ & $\begin{array}{l}\text { Delta-V } \\
\mathbf{( k m / h )}\end{array}$ & $\begin{array}{l}\text { Impact } \\
\text { point }\end{array}$ & PDOF $\left.\mathbf{(}^{\circ}\right)$ & $\begin{array}{l}\text { Force } \\
(\mathbf{N})\end{array}$ \\
\hline $\begin{array}{l}\text { Original } \\
\text { crash (Case } \\
\text { study, } \\
\text { validated) }\end{array}$ & 101 & 82.7 & 14.6 & $\begin{array}{l}\text { Left front } \\
\text { panel }\end{array}$ & -40.6 & 597,820 \\
\hline Roundabout & $\begin{array}{l}66 \\
(-34.6 \%)\end{array}$ & $\begin{array}{l}25.2 \\
(-69.5 \%)\end{array}$ & $\begin{array}{l}3.1 \\
(-78.7 \%)\end{array}$ & $\begin{array}{l}\text { Left-Centre } \\
\text { front panel }\end{array}$ & -63.6 & $\begin{array}{l}104,255 \\
(-82.5 \%)\end{array}$ \\
\hline $\begin{array}{l}\text { Reduced } \\
\text { speed limit } \\
\text { main road }\end{array}$ & $\begin{array}{l}81 \\
(-19.8 \%)\end{array}$ & $\begin{array}{l}50.3 \\
(-39.2 \%)\end{array}$ & $\begin{array}{l}9.5 \\
(-34.9 \%)\end{array}$ & $\begin{array}{l}\text { Left corner } \\
\text { front panel }\end{array}$ & -56.5 & $\begin{array}{l}281,261 \\
(-52.9 \%)\end{array}$ \\
\hline $\begin{array}{l}\text { Rumble } \\
\text { strips }\end{array}$ & $\begin{array}{l}94.6 \\
(-6.3 \%)\end{array}$ & $\begin{array}{l}72 \\
(-12.9 \%)\end{array}$ & $\begin{array}{l}7.2 \\
(-50.6 \%)\end{array}$ & $\begin{array}{l}\text { Left } \\
\text { 'passenger } \\
\text { door' }\end{array}$ & -60.1 & $\begin{array}{l}215,659 \\
(-63.9 \%)\end{array}$ \\
\hline $\begin{array}{l}\text { Reduced } \\
\text { speed limit } \\
\text { main road } \\
\text { plus rumble } \\
\text { strips }\end{array}$ & $\begin{array}{l}74.6 \\
(-26.1 \%)\end{array}$ & $\begin{array}{l}\text { Impact } \\
\text { avoided }\end{array}$ & $\begin{array}{l}\text { Impact } \\
\text { avoided }\end{array}$ & $\begin{array}{l}\text { Impact } \\
\text { avoided }\end{array}$ & $\begin{array}{l}\text { Impact } \\
\text { avoided }\end{array}$ & $\begin{array}{l}\text { Impact } \\
\text { avoided }\end{array}$ \\
\hline
\end{tabular}


Table 3. The kinetic energy of each vehicle prior to impact (percent change from original scenario shown)

\begin{tabular}{|l|l|l|}
\hline Scenario & $\begin{array}{l}\text { Kinetic Energy Pre-Impact } \\
\text { Case vehicle }\end{array}$ & $\begin{array}{l}\text { Kinetic Energy Pre-impact } \\
\text { B-vehicle }\end{array}$ \\
\hline $\begin{array}{l}\text { Original crash (Case study, } \\
\text { validated) }\end{array}$ & 134,798 & $2,653,393$ \\
\hline Roundabout & 541 & 32,619 \\
& $(-99.59 \%)$ & $(-98.8 \%)$ \\
\hline Reduced speed limit main road & 82,803 & $1,003,532$ \\
& $(-38.6 \%)$ & $(-62.2 \%)$ \\
\hline Rumble strips & 72,262 & $2,028,352$ \\
& $(-46.2 \%)$ & NA - impact avoided \\
\hline $\begin{array}{l}\text { Reduced speed limit main road } \\
\text { plus rumble strips }\end{array}$ & NA - impact avoided & \\
\hline
\end{tabular}




\section{APPENDIX 1}

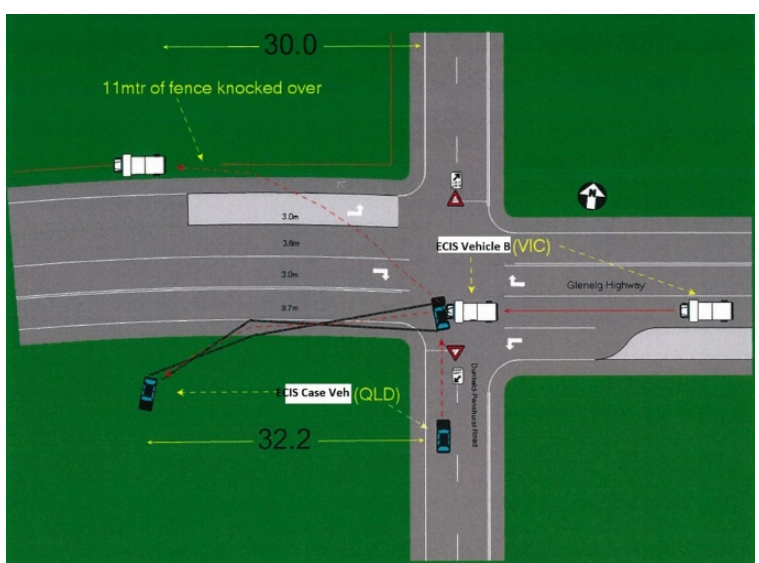

Figure 1 The final rest position of the case and B-Vehicle as noted by police

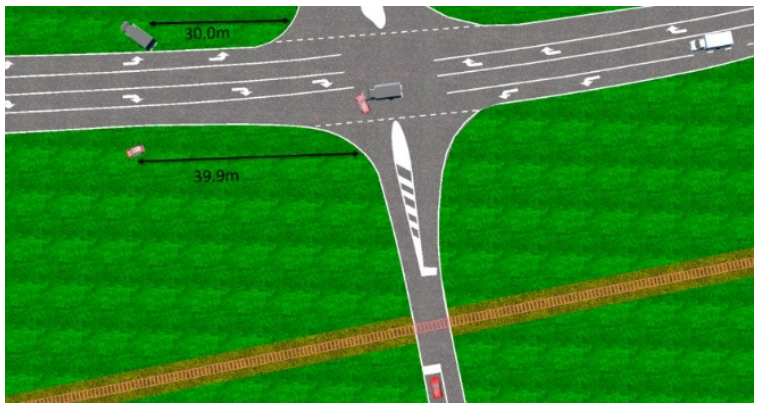

Figure 2. The final rest position of the case and B-vehicle in HVE

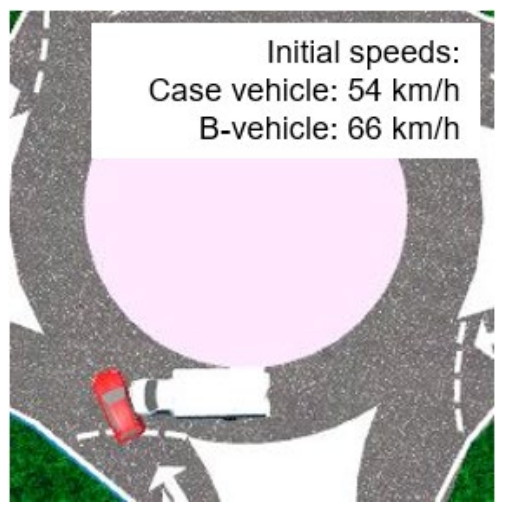

Figure 3. Simulation still showing the point of impact between the case vehicle (red) and B-vehicle (truck) following the installation of a roundabout. 


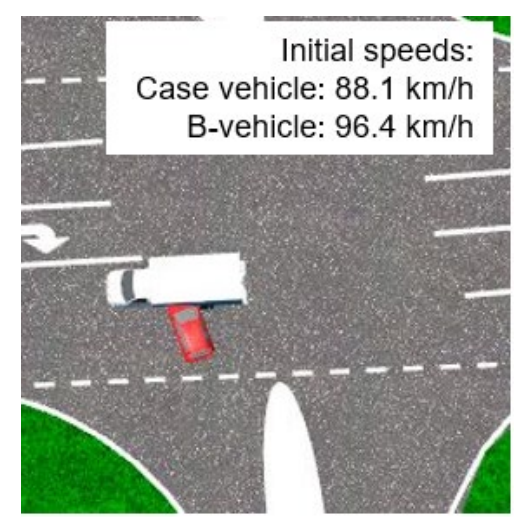

Figure 4. Simulation still showing the point of impact between the case vehicle (red) and B-vehicle (truck) with rumble strips installed $200 \mathrm{~m}$ before the intersection on both approaches.

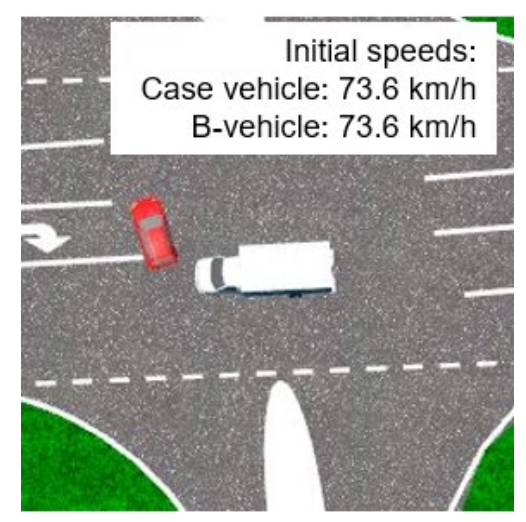

Figure 5. Simulation still showing that the impact between the case vehicle (red) and B-vehicle (truck) is avoided when the installation of rumble strips is accompanied by a speed reduction on the major approach. 